\title{
Logistics Management in the Ghanaian Construction Industry
}

\author{
Boateng Leslie Appiah \\ School of Urban Construction and Civil Engineering, Yangtze University, Jingzhou, China \\ Email:kwadwoleslie@yahoo.com
}

How to cite this paper: Appiah, B.L. (2021) Logistics Management in the Ghanaian Construction Industry. World Journal of Engineering and Technology, 9, 423-443. https://doi.org/10.4236/wjet.2021.93029

Received: March 30, 2021

Accepted: July 24, 2021

Published: July 27, 2021

Copyright $\odot 2021$ by author(s) and Scientific Research Publishing Inc. This work is licensed under the Creative Commons Attribution International License (CC BY 4.0).

http://creativecommons.org/licenses/by/4.0/

\begin{abstract}
In the field of the construction industry, logistics management has become an issue of concern which needs to be focused on in order to ensure effective, successful and timely execution of projects in the construction industry. Logistics management in construction is a multidisciplinary process which makes sure things are done at the right time, cost and quality as well as material supply and handling, schedule control, site infrastructure and equipment location, site physical flow management, traffic arrangements on and around the construction site, and information management related to all physical and services flow. This paper seeks to identify and evaluate the possible factors that affect logistics management in the construction industry and also to ascertain the current practices of inventory management and the effect on logistics management envisage by construction personnel's and stake holders. A descriptive survey research was conducted with both structured and unstructured questionnaire and administered both via e-mail and by sending questionnaire link onto a WhatsApp platform groups of the respondents, and out of the 187 respondents that took part in the survey, 22 respondents feedback were incomplete so 165 member respondents results were analyzed representing $88.2 \%$ response rate. The survey results were analyzed, displayed and interpreted in the form of tables, bar charts, column chart and pie chart with the use of SPSS software. The research survey respondents were comprised of Project Managers, Project Coordinators, Foremen, Site Managers/ Officers, Logistics Managers, Inventory Managers and Laborers. The survey results revealed that majority of the total respondents are in the capacity or position as Logistics Managers and also have from 5 to 10 years working experience, and as well majority of the respondents have also attained Master's degree qualification. It was also revealed that logistics management is greatly affected by the inability or the failure to embrace, adopt and integrate new and emerging technology and its approach into the logistics management system. Majority of the respondents also indicated that in general the adequacy
\end{abstract}


of inventory management system was dissatisfied representing $63.8 \%$ of the total respondents. The construction industry not only needed to improve its inventory management systems but also to ensure appropriate inventory management techniques for enhancing high degree of accuracy, reduced cycle times and replenishment of stock. This usually accounts for the poor delivery and quality of work, accompanied with delays and other associated losses in project construction. For effective Logistics management to be achieved in the construction industry, the introduction of modern technology to carry out logistics functions in the construction industry should be paramount to the industry players.

\section{Keywords}

Logistics Management, Construction Industry, Logistics, Inventory Management, Survey Results

\section{Introduction}

\subsection{Logistics}

The Council of Supply Chain Management Professionals (CSCMP) defines Logistics as that part of supply chain management that plans, creates and monitors the efficient, cost-effective flow and storage of goods, semi-finished items and manufactured products as well as related information between the point of origin and the point of consumption in order to meet customers' requirements and satisfaction [1]. Logistics encompasses all of the information and material flows throughout an organization. It includes everything from the movement of a product or from a service that needs to be rendered, through to the management of incoming raw materials, production, the storing of finished goods, its delivery to the customer and after-sales service [2]. A practical and simple way to look at logistics, as quoted from The Handbook of Technology Management, "is as having the right item in the right quantity at the right time at the right place for the right price in the right condition to the right customer". Logistics operations include manufacturing, purchasing, distribution, the managing of inventories, packaging, and even customer services [3]. The brain behind the outsourcing of logistics services is to: reduce operating costs, meet demand fluctuations and reduce capital investment. The general problems that arise in corporate logistics include delayed and inaccurate information, incomplete services, slow and inefficient operations, and a high product damage rate. The possible consequences are an inability to provide inter-linked services, high operating costs, a rate of high inaccuracy, and a lack of flexibility in responding to changing demand requirements [3].

\subsection{Logistics Management}

Logistics management is a detailed process of organizing and implementing an 
operation, and that detailed process is the flow of work from the beginning to the end, in order to fulfill customer satisfaction and expectations as well as other partners involved. Logistics management consists of the process of planning, implementing and controlling the efficient flow of raw-materials, work-in-progress and finished goods and related information-from point of origin to point of consumption; with a view to providing satisfaction to the customer [4].

Logistics management manages resources that can range from tangible goods (such as materials, equipment and supplies). In so doing, logistics management deals with integrating the flow of information and its management tools, materials handling, production packaging, inventory, transportation, warehousing and sometimes security [5]. The concept of logistics is based on a total system view of the multitude of functions in movement of materials and goods from sources of supply to users. Accordingly, it forces management to think in terms of managing the total system; rather than just one part of it [4].

\subsection{Logistics Management in Construction Industry}

Logistics in construction is a multidisciplinary process which makes sure things are done at the right time, cost and quality, as well as material supply and handling, schedule control, site infrastructure and equipment location, site physical flow management, traffic arrangements on and around the construction site, and information management related to all physical and services flow. Completing construction projects in a timely manner comes with their numerous constrains which requires the skillful integration of many aspects, and one of these aspects which play a crucial role in ensuring that construction projects are completed successfully, is logistics management which also leads to productivity. Construction project sites are impacted by several factors that affect the efficiency of a workforce by reducing their overall productivity. Such a loss of efficiency interferes with the performance of an entire project, and reduces management's chances of meeting project quality, budget, and time objectives. Conversely, by increasing overall productivity through improving logistics management, construction companies would reap many more benefits from their projects [5].

Industry logistics traditionally involve either the contractor going to the supplier to pick up materials or materials been delivered to site. These deliveries occur on an adhoc basis to various locations whether locally and internationally [6]. Only limited management skills and information exchange are commonly employed, the techniques for improving construction logistics include implementing strategic logistics planning across the full supply chain, utilizing consolidation centers, just-in-time delivery to the workplace and adding a logistics specialist to construction project teams [6].

These are mutually inclusive techniques, and other countries have found that construction consolidation centers can reduce $50 \%$ of vehicle movements and $35 \%$ of material waste. Systematic application of supply chain management techniques will address most critical logistics issues and thereby reduce construction 
costs and improve industry performance [6].

Several parallel and independently existing suppliers cross on sites and interact making higher-level planning and coordination a difficult task [7]. A systematic approach to construction logistics has led to the emergence of a dedicated logistics contractor who assumes the single point responsibility to integrate all the essential support services associated with construction project [8]. It highlights the benefits of good logistics as well as the use of consolidation centers on projects and also shows how reduction in transport movements, less money tied up in stock, less waste, and the more efficient use of skilled craftsmen will reduce the cost of projects, reduce construction time, improve quality, reduce risks to health and safety, improve environmental performance and generally improve the image of the industry [8]. Logistics experts offer tried-and-tested ways of achieving these benefits through integrated project teams and supply chains, and the increased adoption of information technology [8].

\section{Literature Review}

\subsection{Logistics System Analysis}

There are different approaches to analyze logistics system. The choice of any approach depends on the kind of analysis that is to be carried out. The four commonly used approaches are materials management versus physical distribution, cost centers, nodes versus links and logistics channels [9]. The best approach to analyze the long run system design of a company's logistics system is nodes versus links. Nodes are spatial points where materials are stored or processed while links are the transportation networks that connect the nodes together [9]. The most appropriate concept applicable to construction logistics on the basis of this research work is nodes versus links because it is concerned with the transportation of materials from supplier/manufacturer's warehouse to the construction site storage and movement of materials within the site from the storage to the point of use. This concept was similarly applied for reverse logistics modeling in construction by [10]. Figure 1 below shows a simple logistics system network that facilitates the delivery of materials to the construction site and subsequent shipment of materials from the storage to the construction area, representing the nodes versus links model of logistics system [11].

\subsubsection{Transportation}

Transportation is the link between the spatial nodes in a logistics system through which materials are moved from one node to another. In construction,

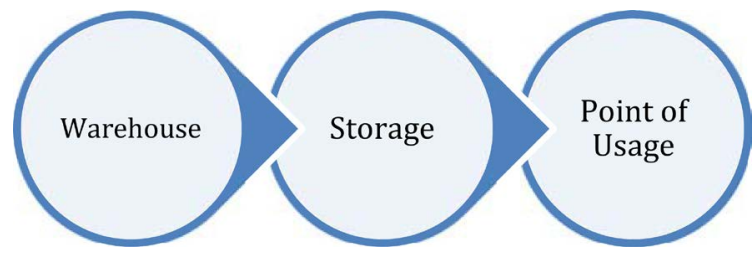

Figure 1. Nodes versus links logistics system. 
enhances the flow of material from the supplier or manufacturer to the construction site. It is the physical distribution channel which connects various important geographically dispersed operating components together within the logistics system. The basic modes of transportation are rail, road, water, air and pipeline (for fluidic materials) [9] [12].

\subsubsection{Warehouse or Site Storage}

Warehouse or Site storage is a node component within nodes versus links logistics system where materials are stored. It is a place where materials are kept prior to being used or fixed on the construction site. Site inventories are monitored with spreadsheet applications which tend to be flawed due to manual processes and inconsistent registering of materials movement [13]. The inability of contractors to provide adequate inventory can result in inefficiencies such as backlogs, capacity mismatch and unavailability of materials [14].

\subsubsection{Material Handling}

Materials' handling on a construction site is the short distance movement of materials within the confines of the site. It is a construction logistics system component that links storage or point of delivery to the construction area. Material handling may be manual, mechanical or combination of both. As [15] emphasized, today's construction projects are highly mechanized and the working environment is dominated by materials handling equipment. The typical applications of plant and equipment include materials handling and lifting operations [16]. An efficient materials handling equipment strongly improves competitiveness through reduction of handling cost, enhances production process, provides effective utilization of manpower and reduces lead time [17].

Construction site materials handling equipment include fork lift trucks, dumpers, hoists and cranes. The selection of equipment can affect the effectiveness and efficiency of the construction site depending on the operating environment of the equipment [18]. In a construction environment where only limited number of materials handling equipment is available, careful planning for the operation of equipment is needed for efficient logistics management on site [19].

\subsection{Classification of Logistical Activities}

A study conducted by Waterz 2003, there are many functions involved in any organization, but there is a function which is called logistics which has the responsibility of the flowing of materials from the supplier into the organization, through the operations within the organization [20]. In the same study Waterz 2003, also stated that almost every organization move material from one point to another point, this operation is the main factor which is the reason of value creation in any organization, and then operations for the conversion of raw material into finished goods and then after finished goods are produced, then those finished goods are delivered to the customers [20]. So materials may come into the organization from the supplier and on the other hand the material may also 
be sent out of the organization to the customers.

\subsubsection{Inbound Logistics}

Inbound logistics is concerned with the smooth and cost effective inflow of materials and other inputs (that are needed in the manufacturing process) from suppliers to the plant. For proper management of inbound logistics, the management has to maintain a continuous interface with suppliers [4].

\subsubsection{Outbound Logistics}

Outbound logistics (also called physical distribution management or supply chain management) is concerned with the flow of finished goods and other related information from the firm to the customer. For proper management of outbound logistics, the management has to maintain a continuous interface with transport operators and channels of distribution [4]. (Figure 2)

\subsection{Key Activities Involved In Logistics Management [4]}

Managing construction projects requires an integrated process to ensure that they are completed on time, within budget, and according to the contract specifications. Labor force productivity enhancement, which typically reduces costs and increases productivity, requires key activities for a successful and efficient logistics management. Table 1 below therefore provides a brief account of key activities involved in logistics management and also tries to describe or explain briefly these various key activities which form the basic foundation in the process of logistics management [4].

\subsection{Logistics Management Relation to Supply Chain Management}

Logistics management is a subset of the larger supply chain management. Supply chain management plans, implements and controls the efficient flow of storage, goods, services and related information from the point of origin to the point of consumption. This is done for the purpose of meeting the requirements of customers [5].

A study conducted by Calipner, 2007 [21] sometimes there are other materials while transporting including pallets, delivery boxes, cable reels and containers. And all these are returned back to the supplier as these are reusable. While there are other materials, which are not reusable, but they are given back to the supplier, for the reason of the recycling including metals, glass, papers, plastics and oils. And then there are materials which are not either brought back for reuse or

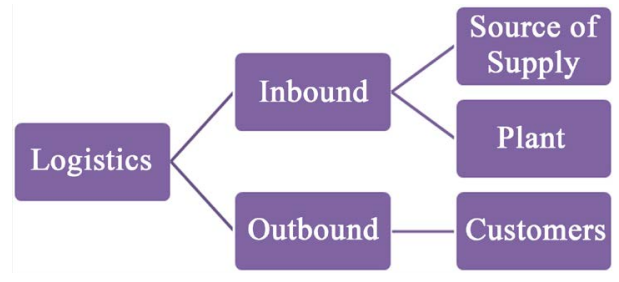

Figure 2. Scope of logistical activities. 
Table 1. Key activities in logistics management.

\begin{tabular}{|c|c|}
\hline ACTIVITIES & BRIEF DESCRIPTION \\
\hline Network Design & $\begin{array}{l}\text { 1. This is one of the prime responsibilities in logistics management and this } \\
\text { network is required to determine the number and location of } \\
\text { manufacturing plants, warehouses, material handling equipment's etc. on } \\
\text { which logistical efficiency depends. }\end{array}$ \\
\hline Order Processing & $\begin{array}{l}\text { 1. This includes activities for receiving, handling, filing and recording of } \\
\text { orders as well as ensuring that order processing is accurate, reliable and } \\
\text { fast. } \\
\text { 2. It has to also minimize the time between receipt of orders and date of } \\
\text { dispatch of the consignment to ensure speedy processing of the orders. }\end{array}$ \\
\hline Procurement & $\begin{array}{l}\text { 1. It is related to obtaining materials from outside suppliers and also } \\
\text { includes supply sourcing, negotiation, order placement, inbound } \\
\text { transportation, receiving and inspection, storage and handling. } \\
\text { 2. Its main objective is to support manufacturing, by providing timely } \\
\text { supplies of qualitative materials at the lowest possible cost. }\end{array}$ \\
\hline Materials Handling & $\begin{array}{l}\text { 1. It involves the activities of handling raw-materials, parts, semi-finished } \\
\text { and finished goods into and out of plant, warehouses and transportation } \\
\text { terminals. } \\
\text { 2. Management has to ensure that the raw-materials, parts, semi-finished } \\
\text { and finished goods are handled properly to minimize losses due to } \\
\text { breakage and spoilage. }\end{array}$ \\
\hline $\begin{array}{l}\text { Inventory } \\
\text { Management }\end{array}$ & $\begin{array}{l}\text { 1. This is to minimize the amount of working capital blocked in inventories } \\
\text { and at the same time to provide a continuous flow of materials to match } \\
\text { production requirements and also to provide timely supplies of goods to } \\
\text { meet customer's demands. } \\
\text { 2. Management has to maintain inventories of raw-materials, parts, } \\
\text { Semi-finished goods and finished goods and also has to balance the } \\
\text { benefits of holding inventories against costs associated with holding } \\
\text { inventories like - storage space costs, insurance costs, risk of damage and } \\
\text { spoilage in keeping stocks. }\end{array}$ \\
\hline $\begin{array}{l}\text { Packaging and } \\
\text { Labeling }\end{array}$ & $\begin{array}{l}\text { 1. Packaging implies enclosing or encasing a product into suitable packets } \\
\text { or containers, for easy and convenient handling of the product by both } \\
\text { the seller and specially the buyer which also acts as a silent salesman } \\
\text { thereby facilitating the sale of the product. } \\
\text { 2. Labeling means putting identification marks on the package of the } \\
\text { product which provides information about date of packing and expiry, } \\
\text { weight or size of product, instructions for safe handling of the product, } \\
\text { price payable by the buyer. }\end{array}$ \\
\hline Storage/Warehousing & $\begin{array}{l}\text { Storage or warehousing is that logistical activity which creates time utility } \\
\text { by storing goods from the time of production till the time these are } \\
\text { needed by ultimate consumer. }\end{array}$ \\
\hline Transportation & $\begin{array}{l}\text { 1. This is needed for Movement of raw-materials from suppliers to the } \\
\text { manufacturing unit. } \\
\text { 2. There is movement of work-in-progress within the plant and movement } \\
\text { of finished goods from plant to the final consumers. }\end{array}$ \\
\hline
\end{tabular}

recycling but for safe disposal which includes dangerous chemicals. And such activities which bring back the materials to the organization are known to be the management of reverse logistics or reverse distribution.

According to Bowersox et al., 2007, the creation of value in the supply chain of any organization is due to logistics management in different ways like manage- 
ment of the services to the customer, orders stocks, the shipment and transport services, storing, the handling, information, forecasting and procurement, cross docking, direct delivery, warehousing and distribution [22]. According to Zhang 2005 logistics management is also stated that it's not only the physical flow of products but also the flow of the information, which is the reason that the whole supply chain linkage [23].

Logisticians focus on inventory management, purchasing, transportation, warehousing, consultation and the organization and mapping of these processes.

\subsection{Types of Logistics Management}

There are four main types of logistics management, each emphasizing a different aspect of the supply process [5]. These are elaborated below:

\subsubsection{Supply Management and Logistics}

This involves the planning, procuring and coordinating materials which are needed at a certain time at a particular place for the production of a task. This includes transportation of the materials as well as a place to store them. Additionally, evaluating the level of supply at the different stages of the process is required to make sure the needs of the customer are met, for example delivering materials to a construction site or parts for a manufacturing plant [5].

\subsubsection{Distribution and Material Movement}

This usually involves taken stored materials and transporting them to where they need to go. The issues in this involve moving materials; including loading, unloading and transportation, as well as keeping track of the stock and how it is used. This type of management controls the movement of supplies from a central warehouse to the stores that sell the product to the public [5].

\subsubsection{Production Logistics and Management}

This manages the stages of combining distributed supplies into a product, such as coordinating what is needed to make or put together something. This involves the staging of materials at the right time to work with the building of a project. This type of logistics management falls in the realm of project management [5].

\subsubsection{Reverse Logistics and Product Return}

This is about the management of reclaiming materials and supplies from production. For example, on a construction site it involves the removal of excess material and returning those materials to one's stock. It can also refer to the return of unwanted or unused products from the end customer seeking a refund [5].

\subsection{The Distribution Network of Logistics Management}

Figure 3 below shows the various links and points of distribution in a logistics management network system. 


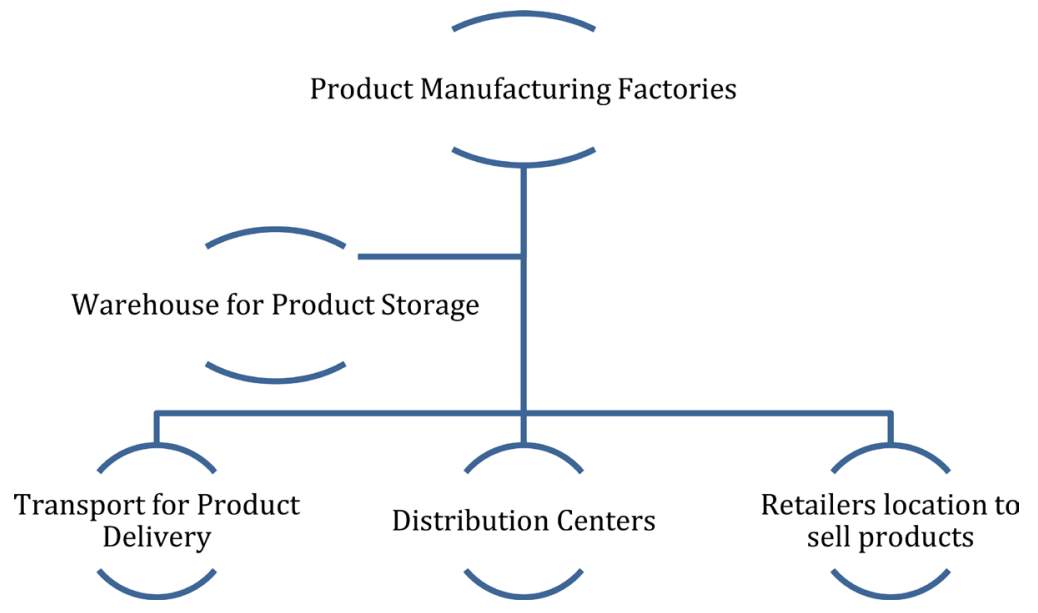

Figure 3. Distribution network of logistics management.

\subsection{Significance of Logistics Management}

Logistics management is significant for the following reasons [4].

- Cost Reduction and Profit Maximization;

- Logistics management results in cost reduction and profit maximization; this is primarily due to improved material handling, Safety, speedy and economical transportation, optimum number and convenient location of warehouses.

- Efficient Flow of Manufacturing Operations;

- Inbound logistics helps in the efficient flow of manufacturing operations, due to on-time delivery of materials, proper utilization of materials and semi-finished goods in the production process;

- Competitive Edge;

- Logistics provide, maintain and sharpen the competitive edge of an enterprise by increasing sales through providing better customer service, arranging for rapid and reliable delivery and also avoiding errors in order processing;

- Effective Communication System;

- Logistics management helps in developing effective communication system for continuous interface with suppliers and rapid response to customer enquiries;

- Sound Inventory Management.

This is a by-product of logistics management. A major headache of production management and financial management is how to ensure effective sound inventory management but such headache is cured by logistics management.

Logistics management therefore helps to drive up revenue, improves customer service, and adds to the company's good reputation and brand, which in turn creates new and more business. With more visibility into the supply chain there is the opportunity to save costs in operations, by controlling inbound funds, keeping inventory at the right level and organizing the reverse flow of goods.

\section{Methodology}

A descriptive survey research was conducted with the use of both structured and unstructured questionnaires which was administered randomly to a sample of 
stakeholders within various sectors of the Construction Industry via email and by sending questionnaire link onto their WhatsApp group platforms for them to respond. They respondents included Logistics Managers, Project Managers, Project Coordinators, Foremen, Site Managers, Laborers, Inventory Manager and others.

\subsection{Questionnaire Structure}

The questionnaire structure of this survey was divided into three parts. The first section aims to collect the background information or the profile analysis of the respondents, e.g. their educational qualification, work experience and professional background. The second section seeks to identify and evaluate the possible factors that affect logistics management in the construction industry. The third section also seek to ascertain the current practices of inventory management and the effect on logistics management envisage by construction personnel's and stake holders.

\subsection{Questionnaire Design}

The survey questionnaire was designed and formulated by looking through the relevant literatures in the area of logistics management in construction industry and then a pilot survey or study was conducted. The pilot survey responses formed the basis of modifying the questionnaire for the subsequent full-scale survey and therefore new inputs raised by the respondents were incorporated in in the final full scale survey questionnaire.

Out of the 187 respondents that took part in the survey, 22 respondents feedback were incomplete so 165 member respondents results were analyzed representing $88.2 \%$ response rate. The survey results were analyzed, displayed and interpreted in the form of tables, bar charts, column chart and pie chart.

\section{Results Analysis and Discussions}

The survey results were analyzed using Statistical Package of Social Studies (SPSS) software. This software is one of the management tools that help in analyzing data and then comes out with a more credible and meaningful results and interpretations.

\subsection{Respondents' Profile Analysis}

Table 2 and Figure 4 describe the distribution of respondents based on their area of specialization, profession or position. 7.3\% of the respondents are Project Managers, $10.3 \%$ are Project Coordinators, $18.2 \%$ are Foremen, $15.8 \%$ are Site Managers/Officers, $21.2 \%$ are Logistics Managers, $13.9 \%$ are Inventory Managers, $8.5 \%$ are Laborers and $4.8 \%$ of the remaining respondents represent other positions. It can therefore be deduced that majority of the Respondents that took part in the research survey are in the portfolio as Logistics Managers representing $21.2 \%$ of the total respondents. In accordance with this, it can be inferred that, 
Table 2. Respondents area of specialization, profession or position.

\begin{tabular}{cccc}
\hline Numbers & Specialization/Profession/Position & $\begin{array}{c}\text { Number of } \\
\text { Respondent }\end{array}$ & $\begin{array}{c}\text { Percentage (\%) of } \\
\text { Respondents }\end{array}$ \\
\hline 1 & Project Managers & 12 & 7.3 \\
2 & Project Coordinators & 17 & 10.3 \\
3 & Foremen & 30 & 18.2 \\
4 & Site Managers/Officers & 26 & 15.8 \\
5 & Logistics Managers & 35 & 21.2 \\
6 & Inventory Managers & 23 & 13.9 \\
7 & Laborers & 14 & 8.5 \\
8 & Others & 8 & 4.8 \\
& TOTAL & 165 & 100 \\
\hline
\end{tabular}

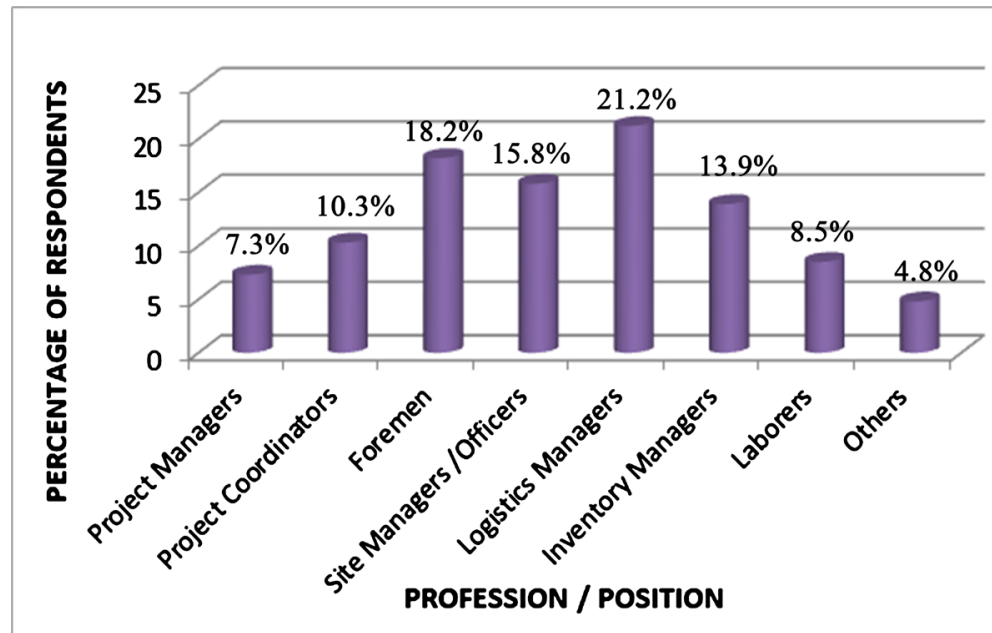

Figure 4. Percentage area of profession or position of respondents.

majority of the respondents who took part in the survey therefore have ample knowledge in the field of logistics management in the construction industry which make the respondents reliable and credible sources of information which is required to satisfy the research goal.

According to Table 3 and Figure 5, 8.5\% of the respondents have less than 1 year working experience, $24.2 \%$ also have from 1 to 3 years working experience, $19.4 \%$ also have more than 3 to 5 years working experience, $30.9 \%$ also have more than 5 to 10 years working experience, $10.9 \%$ also have more than 10 to 15 years working experience and $6.1 \%$ of the total respondents also have over 15 years working experience. It can therefore be deduced that majority of the respondents fall within more than 5 to 10 years working experience, representing $30.9 \%$ of the total respondents.

From Table 4 and Figure 6, 14.5\% of the respondents have attain PHD qualification, $35.8 \%$ of the respondents have Master's Degree qualification, $29.1 \%$ also have Bachelor Degree qualification and the remaining 20.6\% represent Other 
Table 3. Years of working experience of respondents.

\begin{tabular}{cccc}
\hline Numbers & Years of Working Experience & $\begin{array}{c}\text { Number of } \\
\text { Respondent }\end{array}$ & $\begin{array}{c}\text { Percentage (\%) of } \\
\text { Respondents }\end{array}$ \\
\hline 1 & Less than 1 year & 14 & 8.5 \\
2 & From 1 to 3 years & 40 & 24.2 \\
3 & More than 3 to 5 years & 32 & 19.4 \\
4 & More than 5 to 10 years & 51 & 30.9 \\
5 & More than 10 to 15 years & 18 & 10.9 \\
6 & Over 15 years & 10 & 6.1 \\
& TOTAL & 165 & 100 \\
\hline
\end{tabular}

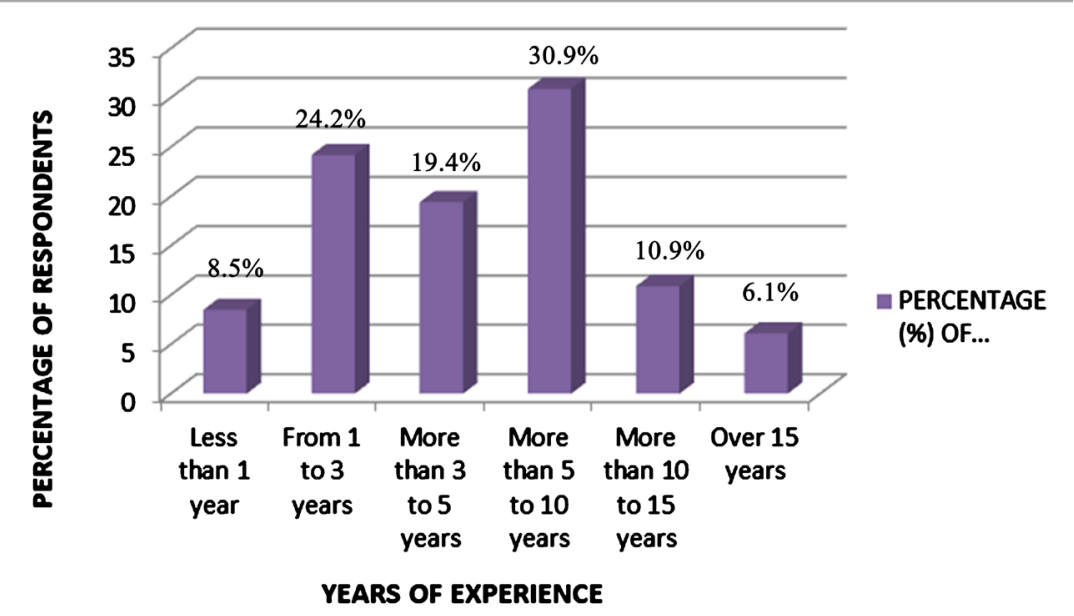

Figure 5. Percentage years of working experience of respondents.

Table 4. Qualification of respondents.

\begin{tabular}{cccc}
\hline Numbers & Qualificaions & $\begin{array}{c}\text { Number of } \\
\text { Respondent }\end{array}$ & $\begin{array}{c}\text { Percentage (\%) of } \\
\text { Respondents }\end{array}$ \\
\hline 1 & PHD & 24 & 14.5 \\
2 & Masters & 59 & 35.8 \\
3 & Bachelors Degree & 48 & 29.1 \\
4 & Others & 34 & 20.6 \\
& TOTAL & 165 & 100 \\
\hline
\end{tabular}

qualifications. It can therefore be inferred from the table and figure above that a total majority of the respondents have attain the requisite qualification to be in the construction industry representing $79.4 \%$ of the entire respondents. This therefore revealed that the majority of the respondents have the needed qualification and therefore have ample knowledge in contributing to success of the survey.

According to Table 5 and Figure 7, 13.9\% of the respondents fall within the ages of $20-29$ years, $46.1 \%$ of the respondents also fall within the ages of $30-39$ 


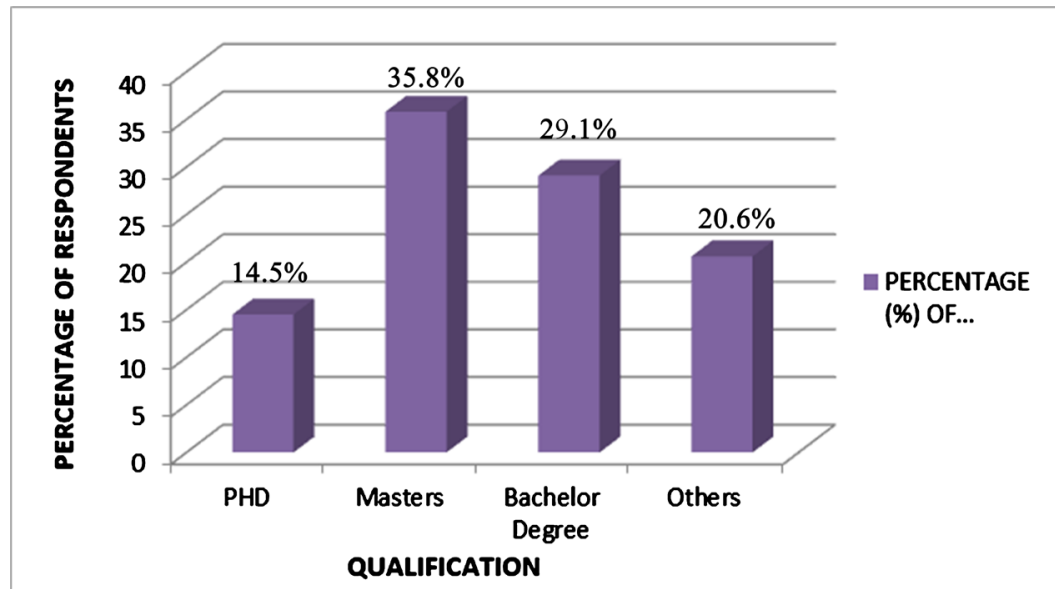

Figure 6. Percentage educational qualification of respondents.

Table 5. Age of respondents.

\begin{tabular}{cccc}
\hline Numbers & Age Range of Respondents & $\begin{array}{c}\text { Number of } \\
\text { Respondent }\end{array}$ & $\begin{array}{c}\text { Percentage (\%) of } \\
\text { Respondents }\end{array}$ \\
\hline 1 & $20-29$ years & 23 & 13.9 \\
2 & $30-39$ years & 76 & 46.1 \\
3 & $40-49$ years & 47 & 28.5 \\
4 & $50-59$ years & 19 & 11.5 \\
& TOTAL & 165 & 100 \\
\hline
\end{tabular}

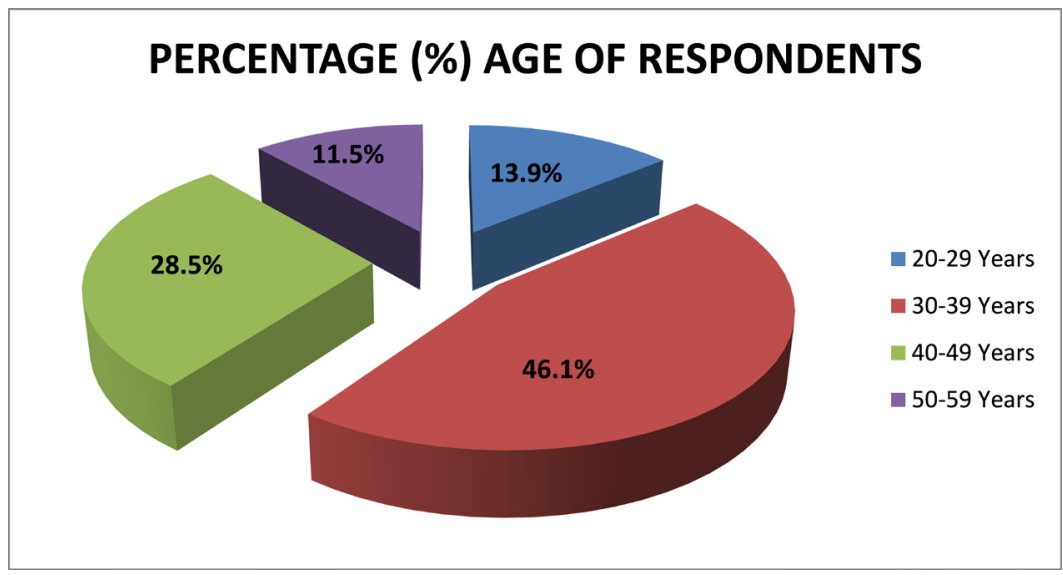

Figure 7. Percentage age of respondents.

years, $28.5 \%$ of the respondents is also within the ages of 40 - 49 years and $11.5 \%$ of the respondents are within the age range of $50-59$ years. It can therefore be deduced that majority of the Respondents fall within 30 - 39 year age group representing $46.1 \%$ which form more than one-third of the total respondents.

\subsection{Results of the Possible Factors That Affect Logistics Management in the Construction Industry}

In accordance with the survey conducted, the questionnaire was also design for 
the respondents to identify, evaluate and also share their opinions on some of the possible factors which affect logistics management in the industry.

The results of this were analyzed and presented in the form of a bar chart. Table 6 and Figure 8 below illustrates the analyzed results of the possible factors or situations that affect logistics management in the industry, as enumerated by the respondents.

From Table 6 and Figure 8, majority of the respondents were of the assertion that failure to adopt the new and emerging technological approach as well as integrating it into the logistics management system is the most possible factor affecting logistics management which is represented by $36.4 \%$. $22.4 \%$ of the respondents also reported on lack of proper communication and the flow of information between parties that are involved, $15.8 \%$ of the respondents also attributed Ineffective inventory management as a factor affecting logistics management. $12.7 \%$ also raised issues pertaining to the Ordering process used in logistics management. $8.5 \%$ also attributed the Planning, Scheduling and Procurement process as a factor which also affect logistics management. $4.2 \%$ represent other factors that were believed to be affecting logistics management as stated by

Table 6. Factors affecting logistics management.

\begin{tabular}{cccc}
\hline Numbers & Possible Factors & $\begin{array}{c}\text { Number of } \\
\text { Respondent }\end{array}$ & $\begin{array}{c}\text { Percentage (\%) of } \\
\text { Respondents }\end{array}$ \\
\hline 1 & $\begin{array}{r}\text { Inefficient Planning, Scheduling and } \\
\text { Procurement process }\end{array}$ & 14 & 22.4 \\
2 & Communication and flow of information & 37 & 15.8 \\
3 & Ineffective Inventory management & 26 & 36.4 \\
4 & Failure to adopt new and emerging & & 12.7 \\
6 & Technology & 60 & 4.2 \\
& Ordering Process & 21 & 100 \\
\hline
\end{tabular}

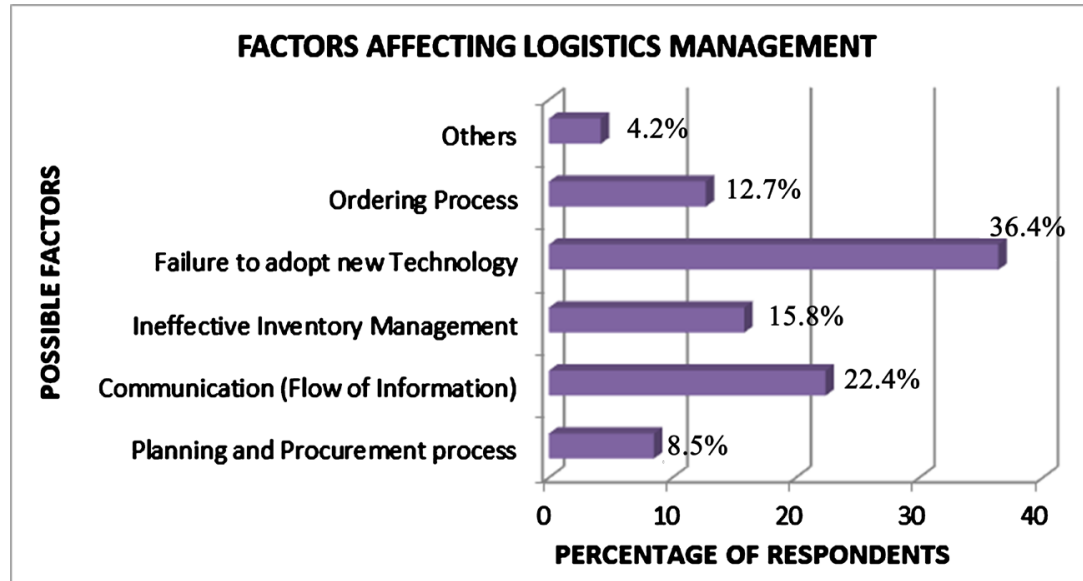

Figure 8. Percentage respondents of factors affecting logistics management. 
the respondents. This result therefore revealed that the failure in adoption of new and emerging technological approach as well as integrating it into the logistics management system is the most contributing factor affecting logistics management in the construction industry.

With regards to the survey conducted, findings from the study therefore accentuate that the integration and incorporation of new and emerging Technology in logistics management in the construction industry goes a long way to have impact or influence on all the other factors enumerated in the analysis. Technology facilitates communication and the flow of information among the various personnel's and stakeholders involved in logistics management and its supply chain. Information technology integration enhances quality, reduces time and costs, enhances competitiveness and generates future growth. Information technology sharing also aids in swift and smooth accomplishment of inventories aiding in fast decision making. Technology also promotes and facilitates more frequently the Planning, Scheduling, Procurement and Ordering processes which contribute to effective and timely supply logistics in the construction industry. Technology also helps managers in redesigning of strategy to add more value to resources when the need arises.

\subsection{Reliability Analysis}

The most common reliability coefficient is the Cronbach's alpha which estimates internal consistency by determining how all variables (factors) on a test relate to all other items and to the total test-internal coherence of data. The reliability is expressed as a coefficient between 0 and 1.00. The higher the coefficient, the more reliable is the test. In this study to ensure the reliability, the Cronbach's Alpha was used. The Cronbach Alpha value is widely used to verify the reliability of the variables. Therefore, Cronbach Alpha was used to test the reliability of the proposed study results. This is shown in Table 7 below.

The significance was 5\% (0.05). The findings indicated that Technology had a reliability Cronbach's value or coefficient of 0.897 , Communication and the flow of Information had a Cronbach's Alpha value of 0.843, Inventory Management showed an Alpha value of 0.752, Ordering Process also had an Alpha value of

Table 7. Reliability Test on Factors affecting Logistics management.

\begin{tabular}{cccc}
\hline $\begin{array}{c}\text { Reliability } \\
\text { Cronbach's Alpha }\end{array}$ & Factors & $\begin{array}{c}\text { Number of } \\
\text { Respondent }\end{array}$ & $\begin{array}{c}\text { P-Significant } \\
\text { Values }\end{array}$ \\
\hline 0.685 & $\begin{array}{c}\text { Inefficient Planning, Scheduling and } \\
\text { Procurement process }\end{array}$ & 14 & 0.0189 \\
0.843 & Communication and flow of information & 37 & 0.0085 \\
0.752 & Ineffective Inventory management & 26 & 0.0103 \\
0.897 & Failure to adopt new and emerging Technology & 60 & 0.0015 \\
0.729 & Ordering Process & 21 & 0.0156 \\
0.656 & Other Factors & 7 & 0.0246 \\
\hline
\end{tabular}


0.729, Planning, Secluding and Procurement process as well had an Alpha value of 0.685 and the remaining other factors also collectively had a reliability Cronbach's Alpha value or coefficient of 0.656 . This therefore indicates that all variables listed showed that, the value of Cronbach's Alpha are all above the suggested Alpha value or coefficient of 0.6 , and this therefore implies that the study results were reliable. On the basis of reliability test it was supposed that the scales used in this study is reliable to capture the independent variables. The significant $\mathrm{P}$-values of the variables under study were satisfying the required threshold where Technology had a significant value (p-value) of 0.0015 , Communication and the flow of Information showed a significant value of 0.0085 , Inventory Management had a significant value of 0.0103 , Ordering Process also had a significant value of 0.0156, Planning, Secluding and Procurement process also had a significant value of 0.0189 and the remaining other factors also collectively had a significant value of 0.0246 .These significant values of the variables are less than 0.05 so in such a case, it accentuates and also confirms to the reliability of the study results.

\subsection{Regression Analysis}

\subsubsection{Inferential Analysis}

Precisely, this study needed to establish relationship between the sub variable (indicators) of each of the factors affecting the efficiency of logistics management as well the relationship with the dependent variable. The inferential statistics analysis aimed to reach conclusions that extend beyond the immediate data alone between the independent variables in this study. The coefficient of correlation ( $r$ ), determine the degree (strength) of relationship and its value is between -1 and 1 . A value 0 implies no relationship, 1 implies a perfect positive relationship, -1 means a negative relationship. An absolute value of $r$ between 0.5 and less than 1 implies a strong relationship between the variables. If the value $r$ is greater than 0.3 and less than 0.5 then the relationship is moderate. The relationship is weak if the value of $r$ is less than 0.3. This inferential analysis involved Chi-square tests. The hypotheses were:

$\mathrm{H}_{0 \mathrm{i}}$ : There is no relationship between Technology and the efficiency of logistics management in the construction industry.

$\mathrm{H}_{0 \mathrm{ii}}$ : There is no relationship between Communication or the flow of Information and the efficiency of logistics management in the construction industry.

$\mathrm{H}_{\text {oiii: }}$ : There is no relationship between Inventory management and efficiency of logistics management in the construction industry.

$\mathrm{H}_{0 \mathrm{iv}}$ : There is no relationship between Ordering process and efficiency of logistics management in the construction industry.

$\mathrm{H}_{\mathrm{ov}}$ : There is no relationship between Planning, Secluding and Procurement processes and efficiency of logistics management in the construction industry.

$\mathrm{H}_{0 \mathrm{iv}}$ : There is no relationship between other collective factors and efficiency of logistics management in the construction industry. 


\subsubsection{Chi-Square Test Analysis}

The null hypothesis was undertaken for analysis. The chi-square $\left(\chi^{2}\right)$ test is used to determine whether there is a significant difference between the expected frequencies and the observed frequencies in one or more categories. To achieve this, a Chi-square $\left(\chi^{2}\right)$ test of significance was used to determine whether or not a relationship other than chance existed between the variables investigated. The Chi-square test is a statistical approach that is often used to test the null hypotheses and this is able to verify whether the row and column variables are independent (The Pearson Chi-square). The calculated Chi-square was computed and then compared with the critical points of the theoretical Chi-square distribution to produce an estimate of how likely or unlikely this calculated value was if the two variables were in fact independent. Any decision to reject the null hypothesis was based on the probability or the observed significance level. The study tested for the null hypotheses and it is displayed in Table 8 below.

According to the results from Table 8, the Chi -square analysis with regards to Technology showed a value of 67.254 at a degree of freedom of 2 . The Chi-square value is found to be more than $\mathrm{P}$ value of 0.0015 . Therefore the null hypothesis is rejected. This therefore means that there exist a relationship between Technology and the efficiency of logistics management. The second hypothesis was Communication and Information flow does not affect nor has no relationship with the efficiency of logistics management. The chi-square analysis showed a value of 48.438 at a degree of freedom of 2 . This Chi-square value is found to be more than $\mathrm{P}$ values of 0.0085 . Therefore the null hypothesis is also rejected, which also means that there exist a relationship between Communication or the flow of Information and the efficiency of logistics management. The third hypothesis states that there is no relationship between Inventory management and efficiency of logistics management. But from the Chi-square results above, the Pearson Chi-square value of 39.942 at a degree of freedom of 2 was established at $\mathrm{P}$-value of 0.01031 . Since the Chi-square value is more that the $\mathrm{P}$-value hence the null hypothesis is also rejected. This also depicts that there is a relationship between Inventory management and efficiency of logistics management. The fourth hypothesis states that there is no relationship between Ordering Process and efficiency of logistics management but the Chi-square analysis

Table 8. Chi-square test between the factors and efficiency of logistics management.

\begin{tabular}{cccc}
\hline $\begin{array}{c}\text { Chi-square } \\
\text { values }\end{array}$ & Factors (Varaibles) & $\begin{array}{c}\text { Degree of } \\
\text { Freedom }\end{array}$ & $\begin{array}{c}\text { P-Significant } \\
\text { Values }\end{array}$ \\
\hline 67.254 (a) & New and Emerging Technology & 2 & 0.0015 \\
48.438 (a) & Communication and the flow of information & 2 & 0.0085 \\
39.942 (a) & Inventory management & 2 & 0.0103 \\
24.258 (a) & Ordering Process & 2 & 0.0156 \\
19.271 (a) & Planning, Scheduling and Procurement process & 2 & 0.0189 \\
11.369 (a) & Other Factors & 2 & 0.0246 \\
\hline
\end{tabular}


value of 21.258 at a degree of freedom of 2 is found to be more than its P-value of 0.0156 . Since the Chi-square value is more than the P-value, it means that there is a relationship between the Ordering process and the efficiency of logistics management thereby signifying the rejection of the null hypothesis. With regards to the fifth hypothesis, the Chi-square value of 19.271 at a degree of freedom of 2 was established at a P-value of 0.0189 . And since the Chi square value is also more than the $\mathrm{P}$-value then it means there is a relationship between Planning, Secluding and Procurement processes and the efficiency of logistics management. So the null hypothesis is also rejected. The last hypothesis too was tested and it came out that the other factors collectively have a Chi-square value of 11.369 at a degree of freedom of 2 with a P-value of 0.0246 , which also depicts that there is a relationship between the factors and the efficiency of logistics management.

Inference can therefore be made based on the Chi-square values at a degree of freedom of 2 and the P-values of the results as shown in Table 8 that, there is a relationship between the dependent and the independent variables of the survey results conducted in the construction industry.

\subsection{Results of the Current Practices of Inventory Management and Its Effects on Logistics Management}

In order to ascertain the current inventory practices that are utilized and its effect on logistics management, respondents were also made to respond to the inventory techniques that are been used at their places of work. In view of this, the respondents were asked to indicate how often they run out of inventory in the course of their work and Figure 9 below display the analyzed results from the respondents.

The majority of the respondents indicated that, they experienced out of stock inventory Monthly representing $47 \%$ of the total respondents, $21 \%$ of them also indicated of experiencing out of stock inventory Quarterly, $14 \%$ also experience it Weekly, $10 \%$ as well experience it Yearly and $8 \%$ of the respondents also accepted of running out of stock on daily basis.

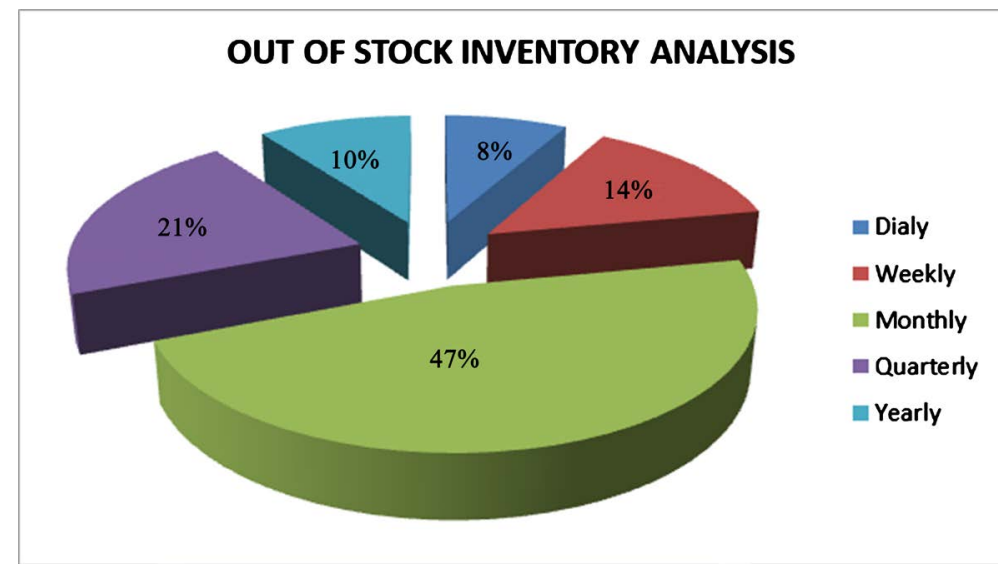

Figure 9. Out of stock inventory analysis by the respondents. 
The respondents were further presented with statements concerning the overall satisfactory reaction pertaining to their current inventory practices to describe how they feel about it. In this case, they were required to tick the statement that best described their opinion. They were to rate the statements on a 5 point Likert scale where $1=$ Highly Satisfied; $2=$ Satisfied; $3=$ Neutral; $4=$ Dissatisfied; $5=$ Strongly Dissatisfied. According to the analysis of findings, the respondents indicated that in general the adequacy of inventory management system was Dissatisfied representing 63.8\% which implied that majority of the respondents coalesced around the same response without differing to a great extent across the entire inventory management.

The findings of the study showed that construction industry not only needed to improve its inventory management systems but also to ensure appropriate inventory management techniques for enhancing high degree of accuracy, reduced cycle times and replenishment of stock. Therefore the need for a proper inventory management in the industry could not be over emphasized given the nature of the firm's operation where equipment and components used are usually very sophisticated. This therefore indicates that the current practices of inventory management in the construction industry have a major effect on the logistics management.

\section{Conclusion}

The research survey came out with a concrete finding that technology affects the efficiency of logistics management and performance in construction industry, trade and even in distribution firms. With regards to the survey conducted, Technology is a major determinant of the efficiency of the logistics management and its performance. It was clear from the study that Technology ensures future viability for the industry and its introduction will greatly increase the ability of logistic firms to conduct their business faster and more accurate over a wide range of time at reduced cost and also achieving customer satisfaction. In conclusion the inability or the failure to embrace, adopt and integrate new and emerging technology and its approach into the logistics management system as well as ineffective inventory managements could have a significant impact to the effective logistics management as indicated by the respondents in study.

\section{Recommendation}

For effective Logistics management to be successfully achieved in the construction industry, the study recommends the introduction of modern technology to carry out logistics functions in the construction industry, and this should also be considered as paramount to the industry players because it will go a very long way to make logistics management very easier and convenient for the stake holders and construction industry players who are much into logistics management. The industry players may also include having current, updated and sophisticated machines and computers with modern software technologies and the needed 
accessories, internet or Wi-Fi which will also contribute to efficiency in logistics management. New concepts are also required to be integrated or incorporated into the logistic management system for the smooth and efficient running of logistics in the construction industry. In relation to the inventory management, the study recommends that there is a need for a total improvement of the existing inventory management systems and practices in order to optimize resources. Logistics managers therefore can also increase employee's productivity when they equip them with modern technology as well as providing in-service training, seminar and conferences to the logistics personnel's in the construction industry.

\section{Acknowledgements}

I want to extend my heartfelt gratitude and appreciation to all of the participants of the study for their responses and priceless cooperation. I also appreciate my friends and colleagues in the construction industry for their invaluable assistance in distributing the research questionnaires link on various platforms for the respondents to also fill them. I say thank you to them all.

\section{Conflicts of Interest}

The author declares no conflicts of interest regarding the publication of this paper.

\section{References}

[1] Council of Supply Chain Management Professionals, CSCMP (2013).

[2] Pollitt, D. (2008) View Point: Getting Logistics on to Boardroom Agenda. International Journal of Physical Distribution and Logistics Management, 28, 168-169.

[3] Bowersox, D.J., Closs, D.J. and Stank, T.P. (2010) Ten-Mega Trends That Will Revolutionize Supply Chain Logistics. Journal of Business Logistics, 21, 1-15.

[4] Logistics Management: Concept, Significance and Key Activities. https://www.yourarticlelibrary.com/business/logistics-management/logistics-manag ement-concept-significance-and-key-activities/69534

[5] Westland, J. (2019) Logistics Management 101: A Beginner's Guide. https://www.projectmanager.com/blog/logistics-management-101

[6] https://www.google.com/url?sa=t\&rct=j\&q=\&esrc=s\&source=web\&cd=\&ved=2ahU KEwj1g-PCt-TxAhVDVs0KHQPKDgsQFjASegQIERAD\&url=https\%3A\%2F\%2Fw ww.buildmagazine.org.nz\%2Fassets\%2FPDF\%2FBuild-134-80-Research-Improving -Construction-Logistics.pdf\&usg=AOvVaw361JgRdwQtvkN35V37Va6-

[7] Voigtmann, J. and Bargstadt, H. (2010) Construction Logistics Planning by Simulation. Proceedings of the 2010 Winter Simulation Conference (WSC), Baltimore, 5-8 December 2010, 3201-3211. https://doi.org/10.1109/WSC.2010.5679012

[8] Sullivan, G., Barthorpe, S. and Robbins, S. (2010) Managing Construction Logistics. Wiley Blackwell, London.

[9] Coyle, J.J., Bardi, E.J. and Langley, C.J. (2003), The Management of Business Logistics: A Supply Chain Perspective. 7th Edition, South-Western Thompson Learning, Mason, Ohio.

[10] Shakantu, W., Muya, M., Tookey, J. and Bowen, P. (2008) Flow Modeling of Con- 
struction Site Materials and Waste Logistics. Engineering, Construction and Architectural Management, 15, 423-439. https://doi.org/10.1108/09699980810902721

[11] Fadiya, O.O. (2012) Development of an Integrated Decision Analysis Framework for Selecting ICT-Based Logistic System in the Construction Industry. PhD Thesis, University of Wolverhampton, Wolverhampton.

[12] Ghiani, G., Laporte, G. and Musmanno, R. (2004) Introduction to Logistics Systems Planning and Control. John Wiley, Hoboken. https://doi.org/10.1002/0470014040

[13] Ala-Risku, T. and Kärkkäinen, M. (2006) Material Delivery Problems in Construction Projects: A Possible Solution. International Journal of Production Economics, 104, 19-29. https://doi.org/10.1016/j.ijpe.2004.12.027

[14] Vidalakis, C., Tookey, J.E. and Sommerville, J. (2011) The Logistics of Construction Supply Chains: The Builders' Merchant Perspective. Journal of Engineering, Construction and Architectural Management, 18, 66-81. https://doi.org/10.1108/09699981111098694

[15] Shapira, A., Lucko, G. and Scexnayder, C.J. (2007) Cranes for Building Construction Projects. Journal of Construction Engineering and Management, 133, 690-700. https://doi.org/10.1061/(ASCE)0733-9364(2007)133:9(690)

[16] Riaz, Z., Edwards, D.J. and Thorpe, A. (2006) Sight Safety: A Hybrid Information and Communication Technology System for Reducing Vehicle/Pedestrian Collisions. Automation in Construction, 15, 719-728.

https://doi.org/10.1016/j.autcon.2005.09.004

[17] Mirhosseyni, S.H.L. and Webb, P. (2009) A Hybrid Fuzzy Knowledge-Based Expert System and Genetic Algorithm for Efficient Selection and Assignment of Material Handling Equipment. Expert Systems with Applications, 36, 11875-11887. https://doi.org/10.1016/j.eswa.2009.04.014

[18] Sertyesilisik, B., Tunstall, A. and Mclouglin, J. (2010) An Investigation of Lifting Operations on UK Construction Sites. Safety Science, 48, 72-79.

https://doi.org/10.1016/j.ssci.2009.06.001

[19] Cho, C.-Y., Kwon, S., Shin, T.-H., Chin, S. and Kim, Y.-S. (2011) A Development of Next Generation Intelligent Construction Liftcar Toolkit for Vertical Material Movement Management. Automation in Construction, 20, 14-27. https://doi.org/10.1016/j.autcon.2010.07.008

[20] Mentzer, J.T., Flint, D.J. and Hult, G.T.M. (2001) Logistics Service Quality as a Segment Customized Process. Journal of Marketing, 65, 82-104. https://doi.org/10.1509/jmkg.65.4.82.18390

[21] Zhang, Z.-J. (2008) Literature Review of Purchasing Management in Service Industry. Management Science and Engineering, 2, 49-53.

[22] Aro-Gordon, S. (2016) Contemporary Inventory Management Techniques: Conceptual Investigation. Icomar, Mysuru, 1-20.

[23] Hamilton, T. (2015) The State of Logistics Performance Measurement: Comparison of Literature and Practice. 